\title{
Characterisation and molecular dynamic simulations of J15 asparaginase from Photobacterium sp. strain J15
}

\author{
Mohd Adilin Yaacob1, Wan Atiqah Najiah Wan Hasan', Mohd Shukuri Mohamad Ali1,2, \\ Raja Noor Zaliha Raja Abdul Rahman 1,4, Abu Bakar Salleh1,3, Mahiran Basri1,5 \\ and Thean Chor Leow ${ }^{1,2,}$,

\begin{abstract}
'Enzyme and Microbial Technology Research Centre; ${ }^{2}$ Department of Cell and Molecular Biology, ${ }^{3}$ Department of Biochemistry, ${ }^{4}$ Department of Microbiology, Faculty of Biotechnology and Biomolecular Sciences; ${ }^{5}$ Department of Chemistry, Faculty of Science, Universiti Putra Malaysia,
\end{abstract} \\ 43400 UPM Serdang, Selangor, Malaysia
}

Genome mining revealed a 1011 nucleotide-long fragment encoding a type I L-asparaginase (J15 asparaginase) from the halo-tolerant Photobacterium sp. strain J15. The gene was overexpressed in pET-32b (+) vector in $E$. coli strain Rosetta-gami B (DE3) pLysS and purified using two-step chromatographic methods: $\mathrm{Ni}^{2+-S e p h a-}$ rose affinity chromatography and Q-Sepharose anion exchange chromatography. The final specific activity and yield of the enzyme achieved from these steps were 20 $\mathrm{U} / \mathrm{mg}$ and $49.2 \%$, respectively. The functional dimeric form of J15-asparaginase was characterised with a molecular weight of $\sim 70 \mathrm{kDa}$. The optimum temperature and $\mathrm{pH}$ were $25^{\circ} \mathrm{C}$ and $\mathrm{pH} 7.0$, respectively. This protein was stable in the presence of $1 \mathrm{mM} \mathrm{Ni}^{2+}$ and $\mathrm{Mg}^{2+}$, but it was inhibited by $\mathrm{Mn}^{2+}, \mathrm{Fe}^{3+}$ and $\mathrm{Zn}^{2+}$ at the same concentration. J15 asparaginase actively hydrolysed its native substrate, L-asparagine, but had low activity towards L-glutamine. The melting temperature of J15 asparaginase was $\sim 51^{\circ} \mathrm{C}$, which was determined using denatured protein analysis of CD spectra. The $K_{\mathrm{m}}, K_{\text {cat }}, K_{\text {cat }} /$ $K_{\mathrm{m}}$ of $\mathrm{J} 15$ asparaginase were $0.76 \mathrm{mM}, 3.2 \mathrm{~s}^{-1}$, and 4.21 $\mathrm{s}^{-1} \mathrm{mM}^{-1}$, respectively. Conformational changes of the $\mathrm{J} 15$ asparaginase 3D structure at different temperatures $\left(25^{\circ} \mathrm{C}, 45^{\circ} \mathrm{C}\right.$, and $\left.65^{\circ} \mathrm{C}\right)$ were analysed using Molecular Dynamic simulations. From the analysis, residues $\mathrm{Tyr}_{24}$ $\mathrm{His}_{22}, \mathrm{Gly}_{23}, \mathrm{Val}_{25}$ and $\mathrm{Pro}_{26}$ may be directly involved in the 'open' and 'closed' lid-loop conformation, facilitating the conversion of substrates during enzymatic reactions. The properties of J15 asparaginase, which can work at physiological $\mathrm{pH}$ and has low glutaminase activity, suggest that this could be a good candidate for reducing toxic effects during cancer treatment.

Key words: J15 asparaginase, Photobacterium sp., expression; purification, Molecular Dynamic (MD) simulations

Received: 30 December, 2013; revised: 27 June, 2014; accepted: 29 September, 2014; available on-line: 22 October, 2014

\section{INTRODUCTION}

L-asparaginase (EC 3.5.1.1) catalyses the hydrolysis of $\mathrm{L}$-asparagine to L-aspartate and ammonia. The enzyme is widely used in the pharmaceutical and food industries. The discovery of asparaginase from guinea pig serum that can inhibit lymphoma, which is a type of blood cancer, in mice resulted in searches for L-asparaginase from different sources which might be useful for the treatment of human cancer (Broome, 1963). Although this enzyme can be found among organisms in different kingdoms, bacterial asparaginase has received more attention with regard to the treatment of cancer for several reasons: ease cultivation, economic feasibility, environmentally friendly and large scale production in a short period of time. L-asparaginase from different microbes have distinct characteristics based on adaptation to their habitat and ecological functions (Warangkar \& Khobrade, 2010).

Bacterial asparaginase can be divided into type I and type II based on the cellular location and affinity towards different types of substrate (Campbell et al., 1967). Type II periplasmic asparaginase displays high specific activity towards L-asparagine and is believed to have neoplastic activity; Hence, type II L-asparaginase is used for clinical applications. Meanwhile, cytoplasmic type I L-asparaginase is constitutively expressed and responsible for cell metabolism. The cytoplasmic type I L-asparaginase was less valuable since it has lower affinity toward the substrate L-asparagine (Schwartz et al., 1966). The first crystal structure of type I bacterial L-asparaginase from the archaea Pyrococcus horikoshii was solved only at $2.6 \AA$ resolution, while the structure of type II L-asparaginase has been studied extensively (Yao et al., 2005). The enzyme was found to be dimeric rather than the common tetrameric architecture of type II L-asparaginase. Despite sharing a high degree of sequence similarity and overall folding, it is not clear why bacterial type II L-asparaginase functions as a tetramer whereas dimerisation provides all of the components of active sites in type I Lasparaginase (Michalska \& Jaskolki, 2006).

The chemotherapeutic nature of asparaginase relies on the ability of the enzyme to maintain low levels of amino acids in the circulatory system, thus starving the cancer cell (Kidd, 1953). Cancers such as acute lymphoblastic leukaemia (ALL), Hodgkin's disease, acute myelocytic leukaemia, chronic lymphocytic leukaemia, acute myelomonocyticleukaemia, and lymphosarcoma, all of which lose the ability to synthesise amino acids themselves, depend heavily on amino acids from the outside in order to cope with their rapid growth (Stecher et al., 1999; Duval et al., 2002). The conversion ofthe amino acid L-asparagine to aspartic acid with L-asparaginase causes the apoptosis of cancer cells.

e-mail: adamleow@upm.edu.my

Abbreviations: $C D$, circular dichroism; $M D$, molecular dynamics; RMSD, root mean square deviation 
In spite of numerous reports on L-asparaginases obtained from Gram negative bacteria, the application of these enzymes is still limited due to the intrinsic glutaminase activity which partially contributes to some side effects during treatment. However, asparaginases from Gram negative bacteria such as Escherichia coli and Erwinia carotovora have been found to be the most effective as they possess lower toxicity and a strong preference to asparagine over glutamine (Duval et al., 2002). Unfortunately, despite the wide usage of L-asparaginase in the past 30 years, the toxicity of the enzyme during treatment is still a major unresolved problem. Organ failure and hypersensitivity that can lead to death have been observed in patients during treatment. Although many improvements have been made to increase the pharmacokinetics, pharmacology and intracellular action of the enzyme, for example PEGylation (Veronese \& Pasut, 2005) and encapsulation (Kwon et al., 2009), none of these approaches eliminated the limitations associated with L-asparaginase during treatment. Therefore, scientists are struggling in the search for a more effective and less toxic L-asparaginase.

Halophilic bacteria possess many hydrolytic enzymes which are capable of functioning under conditions that lead to the precipitation and denaturation of most proteins. In addition, the saline nature of sea water is chemically closer to human blood plasma, and could provide a safer and more effective microbial enzyme with no or less toxicity when used for therapeutic applications. In the present study, we characterised the first reported Lasparaginase from the marine Photobacterium sp. strain J15 to identify its potential for therapeutic applications.

\section{MATERIAL AND METHODS}

Isolation and overexpression of gene. Isolation of full-length asparaginase gene was carried out using the primers Asn-F (5'-ATCGGGATCCATGGAAAGAAAACACATT'TAC-3') and Asn-R(5'ATCGGAAT TCT'T'TAGTGAGT'TAACTCACCC-3') with BamHI and EcoRI restriction sites underlined, respectively. The PCR conditions were as follows: initial denaturation at $95^{\circ} \mathrm{C}$ for $3 \mathrm{~min}$, followed by 35 cycles of denaturation at $95^{\circ} \mathrm{C}$ for $30 \mathrm{~s}$, annealing at $57.4^{\circ} \mathrm{C}$ for $30 \mathrm{~s}$, extension at $72^{\circ} \mathrm{C}$ for $1 \mathrm{~min}$, and a final extension at $72^{\circ} \mathrm{C}$ for $7 \mathrm{~min}$. The amplicons were digested with the restriction endonucleases Bam HI and EcoRI, and ligated into a pET-32b (+) vector that was digested with the same restriction endonucleases. The recombinant construct was then transformed into chemically competent E. coli TOP 10. Successful ligation was confirmed by double digestion and sequencing of the recombinant plasmid. The recombinant plasmid DNA was extracted from the transformants and then transformed into $E$. coli Rosetta-gami $\mathrm{B}$ (DE3) pLysS [genotype: $\mathrm{F}^{-}$omp $T$ hsd $\mathrm{B}_{\mathrm{B}}\left(\mathrm{r}_{\mathrm{B}}{ }^{-} \mathrm{m}_{\mathrm{B}}{ }^{-}\right)$gal dcm lacY1 ahpC (DE3) gor522:: Tn10 trxB pLysSRARE (Cam ${ }^{\mathrm{R}}$, $\mathrm{Kan}^{\mathrm{R}}$, $\left.\mathrm{Tet}^{\mathrm{R}}\right)$ ] for protein expression.

J15 asparaginase assay. The asparaginase activity of J15 asparaginase was performed according to the standard protocol by Shirfin et al. (1974) with slight modifications. In this assay, the rate of ammonia released during the reaction was measured using Nessler reagent. A mixture of $0.05 \mathrm{ml}$ of purified $\mathrm{J} 15$ asparaginase, $0.5 \mathrm{ml} 50$ $\mathrm{mM}$ phosphate buffer ( $\mathrm{pH} 7.4), 0.45 \mathrm{ml}$ deionised water $\left(\mathrm{ddH}_{2} \mathrm{O}\right)$ and $0.05 \mathrm{ml}$ of $0.189 \mathrm{M} \mathrm{L}$-asparagine was incubated for $30 \mathrm{~min}$ at $37^{\circ} \mathrm{C}$. The reaction was stopped by the addition of $0.05 \mathrm{ml}$ of $1.5 \mathrm{M}$ trichloroacetic acids. After centrifugation at $15294 \times g, 0.1 \mathrm{ml}$ of the super- natant was diluted to $2.15 \mathrm{ml}$ with $\mathrm{ddH}_{2} \mathrm{O}$ and treated with $0.25 \mathrm{ml}$ of Nessler's reagent. The colour reaction was allowed to develop for $1 \mathrm{~min}$ and the absorbance was read at $430 \mathrm{~nm}$ with a UV visible spectrophotometer (Ultrospec 2100, GE Healthcare, and USA). The standard was prepared by plotting the absorbance at 436 $\mathrm{nm}$ of the standard versus ammonia $\left(\mathrm{NH}_{3}\right)$ concentration. Ammonia liberated in the sample was extrapolated from a standard curve. One unit (U) of L-asparaginase activity was defined as the rate of liberating $1 \mu \mathrm{mol}$ of ammonia per min under the standard assayed conditions.

Purification of J15 asparaginase. The initial purification step was performed using affinity chromatography with $10 \mathrm{ml}$ of $\mathrm{Ni}^{2+}$-Sepharose HP (GE Healthcare, USA). The cell pellet from a $200 \mathrm{ml}$ culture was resuspended in $20 \mathrm{ml}$ of binding buffer $(50 \mathrm{mM}$ phosphate buffer, $0.5 \mathrm{M} \mathrm{NaCl}, 70 \mathrm{mM}$ imidazole, $\mathrm{pH}$ 7.4). The crude enzyme was loaded into $10 \mathrm{ml}$ of $\mathrm{Ni}^{2+}$-Sepharose HP resin packed into a XK 16/20 column which was previously equilibrated with $50 \mathrm{ml}$ [(equal to 5 column volume $(\mathrm{CV})$ ] of binding buffer at a flow rate of $1 \mathrm{ml} /$ min. The unbound protein was washed with $10 \mathrm{CV}$ of binding buffer. The bound protein was eluted under a gradient step using elution buffer $(50 \mathrm{mM}$ phosphate buffer, $0.5 \mathrm{M} \mathrm{NaCl}$ and $500 \mathrm{mM}$ imidazole, $\mathrm{pH}$ 7.4).

The eluted fractions were treated with thrombin (1 $\mathrm{U} / \mathrm{mg}$ of fusion protein) to remove the Trx-tag at the $\mathrm{N}$-terminal of $\mathrm{J} 15$ asparaginase at $20^{\circ} \mathrm{C}$ for $20 \mathrm{~h}$ and dialysed against phosphate buffer $(20 \mathrm{mM}$ phosphate buffer, $50 \mathrm{mM} \mathrm{NaCl}, \mathrm{pH}$ 6.5). The thrombin-digested fusion protein was loaded into a $5 \mathrm{ml}$ Q-Sepharose column (GE Healthcare, USA) which was pre-equilibrated with binding buffer $(20 \mathrm{mM}$ phosphate buffer, $50 \mathrm{mM} \mathrm{NaCl}$, $\mathrm{pH}$ 6.5). Non-adsorbed protein was washed off with equilibration buffer followed by elution of the bound protein using elution buffer $(20 \mathrm{mM}$ phosphate buffer, $1 \mathrm{M} \mathrm{NaCl}, \mathrm{pH}$ 6.5). Collected fractions $(2 \mathrm{ml})$ were assayed for asparaginase activity. Protein subunits and molecular mass of the purified protein was determined by denaturing gel electrophoresis (12\% SDS/PAGE) and MALDI-TOF/TOF mass spectrometry, respectively. Protein oligomerisation was analysed using native gel electrophoresis $(10 \%$ Native-PAGE). Protein concentration was determined by the Bradford method using bovine serum albumin as a standard (Bradford, 1976).

Characterisation of J15 asparaginase. The purified J15 asparaginase in $50 \mathrm{mM}$ phosphate buffer ( $\mathrm{pH} 7.4)$ was assayed at various temperatures ranging from $15^{\circ} \mathrm{C}$ to $55^{\circ} \mathrm{C}$ using $5^{\circ} \mathrm{C}$ intervals for $30 \mathrm{~min}$, with $\mathrm{L}$-asparagine as a substrate. The stability of the J15 asparaginase was determined by pre-incubating purified $\mathrm{J} 15$ asparaginase for up to $7 \mathrm{~h}$ at $20^{\circ} \mathrm{C}, 25^{\circ} \mathrm{C}$ and $30^{\circ} \mathrm{C}$ in $50 \mathrm{mM}$ phosphate buffer ( $\mathrm{pH}$ 7.4) prior to the asparaginase assay. The $\mathrm{pH}$ profile was determined by assaying the purified $\mathrm{J} 15$ asparaginase using $50 \mathrm{mM}$ of various buffer systems: acetate buffer ( $\mathrm{pH}$ 4.0-6.0), phosphate buffer $(\mathrm{pH}$ 6.0-8.0), Tris/HCl buffer $(\mathrm{pH} 8.0-9.0)$ and glycine- $\mathrm{NaOH}$ buffer ( $\mathrm{pH} 9.0-12.0)$. The effects of various metal ions on J15 asparaginase activity were tested by treating purified J15 asparaginase with $1 \mathrm{mM}$ of metal ions for $30 \mathrm{~min}$ at $25^{\circ} \mathrm{C}, \mathrm{pH} 7.0$. The residual activity was measured using the L-asparaginase assay. The purified J15 asparaginase was treated with different types of inhibitors (PMSF, EDTA, $\beta$-mercaptoethanol and SDS) at a final concentration of $1 \mathrm{mM}$ for $30 \mathrm{~min}$ at $25^{\circ} \mathrm{C}$. The residual activity was measured colorimetrically. The purified J15 asparaginase was also subjected to different types of substrates to check the substrate specificity at $25^{\circ} \mathrm{C}$. 


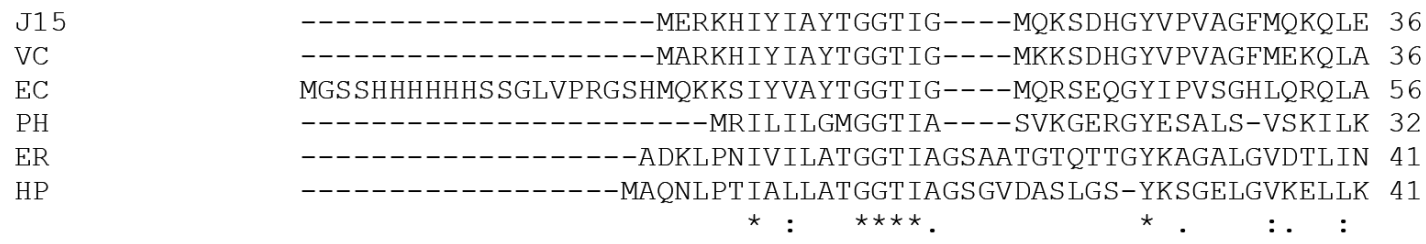

J15 SMPEFQRPEMPKFTIHEYEPLIDSSDMSPADWQRIADDIKENY--DEYDGFVILHGTDTM 94 VC SMPEFHRPEMPLFTIHEYDPLMDSSDMTPADWQLIADDIAANY--DKYDGFVILHGTDTM 94 $\mathrm{EC}$ $\mathrm{PH}$ ER HP LMPEFHRPEMPDFTIHEYTPLMDSSDMTPEDWQHIAEDIKAHY--DDYDGFVILHGTDTM 114 LAGISSEAKIEARDLMN----VDSTLIQPSDWERLAKEIEKEV--WEYDGIVITHGTDTM 86 AVPEVKKLANVKGEQFSN---MASENMTGDVVLKLSQRVNELLARDDVDGVVITHGTDTV 98 AIPSLNKIARIQGEQVSN---IGSQDMNEEIWFKLAQRAQELLDDSRIQGVVITHGTDTL 98

$$
: \star \quad:: \quad:{ }^{\star} \cdot \star \star \star \star \star \star \star *:
$$

J15

$\mathrm{VC}$

$\mathrm{EC}$

$\mathrm{PH}$

ER

HP

J15

$\mathrm{VC}$

$\mathrm{EC}$

$\mathrm{PH}$

ER

HP

J15

VC

EC

$\mathrm{PH}$

ER

HP

J15

VC

EC

$\mathrm{PH}$

ER

HP

J15

$\mathrm{VC}$

EC

$\mathrm{PH}$

ER

HP

AYTASALSFMFENLDKPVIVTGSQI PLAELRSDGQSNLLNSLHIAAN--YPINEVTVFFN 152 AYTASALSFMFENLGKPVIVTGSQI PLADLRSDGQANLLNALHVAAN--YPINEVTLFFN 152 AYTASALSFMLENLGKPVIVTGSQI PLAELRSDGQINLLNALYVAAN--YPINEVTLFFN 172 AYSASMLSFMLRNPPI PIVLTGSMLPITEKNSDAPFNLRTALEFVK---LGIRGIYIAFN 143 EESAYFLHLTVKS-DKPVVFVAAMRPATAISADGPMNLLEAVRVAGDKQSRGRGVMVVIN 157 EESAYFLNLVLHS-TKPVVLVGAMRNASS LSADGALNLYEAVSVAVNEKSANKGVLVVMD 157

$$
: * \quad \text { * } \ldots \quad *:: \ldots: \quad: \quad{ }^{*} . * * \quad:: \ldots \text {. : : : : }
$$

NQLIRGNRSTKAHADGFGAFISPNMPPLLEAGINIQLN-NVELDK--KPEGKFKVHNITP 209 NRLMRGNRSRKSHADGFSAFSSPNLPPLLEAGINIELSTNVKVDE--KPSGEFKVNPITP 210 NRLYRGNRTAKAHADGFDAFASPNLPPLLEAGIHIRRL-NTPPAP--HGEGELIVHPITP 229 GKVMLGVRASK IRSMGFDAFESINYP--NVAEIKDDKLRILHIPD--FYGDEFFSDIKYE 199 DRI GSARYITKTNASTLDTFRANEEGYLG-VIIGNRIYYQNRIDKLHTTRSVFDVRGLTS 216 DTIFSVREVVKTHTTHVSTFKALNSGAIGSVYYGKTRYYMQPLRK-HTTESEESLSQLKT 216

$$
\text { . : } \quad \text {. : . : * : . . . }
$$

--QPIGVITMY PGISPEV IRNTLRQPVNAMI LLTFGVGNAPONPELLAQLKEAADRGVIV 267 --QPIGVITMYPGISHEV IRNTLLQPVNAMI LLTFGVGNAPQNPELLAQLKAASERGVIV 268 --QPI GVVTIY PGI SADVVRNFLRQPVKALI LRSYGVGNAPQNKAFLQELQEASDRGIVV 287 --PKVLVIKLI PGLSGDIVREALRLGYKGIILEGYGVGGIPYRGTDLFEVVSSISKRI PV 257 -LPKVDILYGYQDDPEYLYDAAIQHGVKGIVYAGMGAGSVSVR--GIAGMRKALEKGVVV 273 PLPKVDI IYTHAGMTPDLFQASLNSHAKGVVIAGVGNGNVSAG--FLKAMQEASQMGVVI 274

$$
::: \quad . \quad \text { : : : : : : } \quad \star \star . . \quad: \quad: \quad \text {. : : }
$$

MNLTQCLSGKVNMGGYATGCALADAGVLSGYDMT PEAALAKLHFLLSQDLPLETIRSLMQ 327 VNLTQCLAGKVNMGGYATGCALADAGVISGYDMT PEAALAKLHYLLSQNLSYEEVKAKMQ 328 VNLTQCMSGKVNMGGYATGNALAHAGVIGGADMTVEATLTKLHYLLSQELDTETIRKAMS 347 VLTTQAIYDGVDLQRYKVGRIALEAGVIPAGDMTKEATITKLMWILGHTKNIEEVKQLMG 317 MRS TRTGNGIVPP------DEELPGLVS-DSLNPAHARI LLMLALTRTSDPKVIQEYFH 325 VRSSRVGSGGVTSG----EIDDKAYGEITSDNLNPQKARVLLQLALTKTNDKAKIQEMFE 330

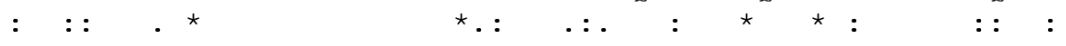

QNLRGELTH-- 336

QVLRGEMTL-- 337

QNLRGELTPDD 358 KNITGELTRVS 328

TY-------- 327

EY--------- 332

Figure 1. Multiple sequence alignment of selected type I L-asparaginases from different species.

The alignment was generated using CLUSTALW (Thompson et al., 1994). Fully conserved region were indicated by $(*)$, deleted region by $(-)$ and conservation of strong and weak groups is denoted by $(:)$ and (.) respectively. The sequences of five intracellular L-asparaginases were shown; J15: Photobacterium sp. strain J15; VC, Vibrio cholerae; EC, cytoplasmic E. coli; PH, Pyrococcus horikoshii; ER, Erwinia crysanthemi; HP, Helicobacter pylori.

Kinetic analysis of $\mathbf{J 1 5}$ asparaginase. The purified J15 asparaginase in $20 \mathrm{mM}$ phosphate buffer ( $\mathrm{pH} 7.0$ ) was incubated with different concentrations of L-asparagine $(2 \mathrm{mM}, 4 \mathrm{mM}, 6 \mathrm{mM}, 8 \mathrm{mM}$ and $10 \mathrm{mM})$ at $25^{\circ} \mathrm{C}$ using various incubation times $(10,20,30,40,50$ and 60 min). The amount of ammonia released was detected by the standard L-asparaginase assay. The kinetic parameters $K_{\mathrm{m}}$ and $K_{\text {cat }}$ were calculated using non-linear regression analysis of experimental steady state data. The linear re- gression analysis was achieved using a Lineweaver-Burke plot $\left(1 / \mathrm{V}_{\mathrm{o}}\right.$ against $\left.1 /[\mathrm{S}]\right)$.

$T_{\mathrm{m}}$ and secondary structure content of J15 asparaginase analysis by circular dichroism (CD). Purified J15 asparaginase in $10 \mathrm{mM}$ sodium phosphate buffer $(\mathrm{pH} 7.0)$ was analysed with the J-810 spectropolarimeter (Jasco, Japan) for CD spectral analysis. The warm-up periods of $10^{\circ} \mathrm{C}$ to $90^{\circ} \mathrm{C}$ and a wavelength scan of 180 to $250 \mathrm{~nm}$ were applied. The variable temperature measure- 
ment of J15 asparaginase was performed by employing $10 \mathrm{~mm}$ cells after checking the $\mathrm{CD}$ value at $220 \mathrm{~nm}$. The warm-up period was $10^{\circ} \mathrm{C}$ to $90^{\circ} \mathrm{C}$, with 1 degree incrementsper minute; the wavelength was set to $220 \mathrm{~nm}$. The concentration was $0.2 \mathrm{mg} / \mathrm{ml}$ and the top of the cell was completely closed using a cap. Datapitch, bandwidth, response, scanning speed, and accumulation were set as $0.1^{\circ} \mathrm{C}, 1 \mathrm{~nm}, 8 \mathrm{~S}, 1^{\circ} \mathrm{C} / \mathrm{min}, 8$ times, respectively. FarUV CD spectra were recorded at a wavelength within the region from 190-240 nm, with a $1.0 \mathrm{~mm}$ path length cuvette containing the native enzyme solutions. The baseline reading was corrected with the respective blank. The raw data from CD spectra were analysed against the reference database from http://perry.freeshell.org.

Homology modelling and MD simulation study. Comparative modelling, molecular docking and Molecular Dynamic (MD) simulations were conducted using the YASARA program (YASARA Biosciences, Austria). The template of Vibrio cholerae L-asparaginase (2OCD) was retrieved from PDB (http://www.rcsb.org/), while ligands (L-asparagine) were taken from the Pubchem compound (http://www.ncbi.nlm.nih.gov/pccompound). Local docking was performed using Auto-Dock 4.2 (Morris et al., 1998) with the default docking parameter and point charges assigned according to the AMBER03 force field (Duan et al., 2003). The setup was done using the YASARA molecular modelling program (Krieger et al., 2002). MD simulation was carried out for $20 \mathrm{~ns}$ at different temperatures $\left(25^{\circ} \mathrm{C}, 45^{\circ} \mathrm{C}\right.$, and $\left.65^{\circ} \mathrm{C}\right)$ in an aqueous environment. The simulation parameters such as water density and counter ion concentrations $\mathrm{Na}^{+}$and $\mathrm{CI}^{-}$) were $0.997 \mathrm{~g} / \mathrm{L}$ and $0.9 \%$, respectively. The simulation was run in truncated orthorhombic cell under periodic boundary conditions. AMBER03 $\mathrm{N}$ force field was applied to all atoms in the system with $7.86 \AA$ cut-offs andnon-bonded interactions. The $\mathrm{pKa}$ values for Asp, Glu, Hisand Lys residues were predicted and the protonation states were assigned according to $\mathrm{pH} 7.0$, which is the optimum $\mathrm{pH}$ of $\mathrm{J} 15$ asparaginase.

\section{RESULTS AND DISCUSSION}

\section{Expression and purification of $\mathrm{J} 15$ asparaginase}

The genome of Photobacterium sp. strain J15 was partially sequenced and a $1011 \mathrm{bp}$ open reading frame (ORF) fortype I L-asparaginase was revealed. This ORF encodes a predicted protein of 336 amino acids with $82 \%$ identity to L-asparaginase from Vibrio cholerae. Figure 1 shows the multiple sequence alignment of the available L-asparaginase from different bacterial species. The conserved residues which are likely to be involved in the catalysis of substratesare $\mathrm{Thr}_{14}, \mathrm{Tyr}_{24}, \mathrm{Thr}_{91}, \mathrm{Asp}_{92}$ and $\mathrm{Ser}_{117}$; $\mathrm{Lys}_{163}$ was found on the J15 asparaginase sequence in agreement with the E. coli asparaginase structure (Sanches et al., 2007). The other residues involved in catalysis are residues 6-38, which contain a flexible loop.

Table 1. Purification table of the intracellular expressed fusion J15 asparaginase from Photobacterium sp. strain J15.

\begin{tabular}{llllllc}
\hline Steps & $\begin{array}{l}\text { Volume } \\
(\mathrm{ml})\end{array}$ & $\begin{array}{l}\text { Total activity } \\
(\mathrm{U})\end{array}$ & $\begin{array}{l}\text { Total protein } \\
(\mathrm{mg})\end{array}$ & $\begin{array}{l}\text { Specific activity } \\
(\mathrm{U} / \mathrm{mg})\end{array}$ & Fold & Yield (\%) \\
\hline Crude extract & 12 & 776.5 & 349.2 & 2.2 & 1.0 & 100.0 \\
\hdashline $\mathrm{Ni}^{2+}$-Sepharose & 8 & 599.0 & 56.0 & 10.7 & 4.9 & 77.1 \\
\hdashline Q-Sepharose & 5 & 382.5 & 18.5 & 20.0 & 10.0 & 49.2 \\
\hline
\end{tabular}

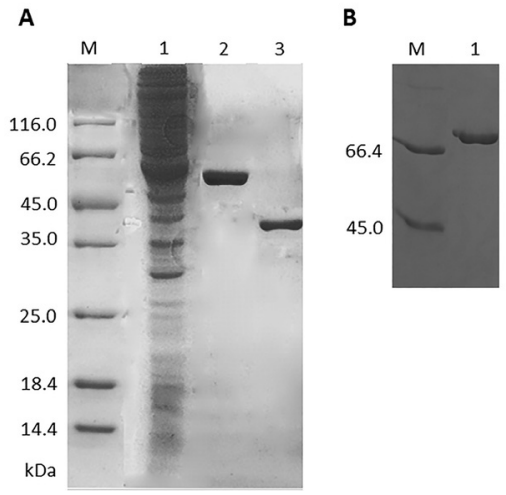

Figure 2. Polyacrylamide gel electrophoresis of J15 asparaginase.

(a) SDS/PAGE (12\%) of $J 15$ asparaginase. M, Unstained protein molecular marker; Lane 1, crude extract; Lane 2, Purified J15 asparaginase after Nickel Sepharose chromatography 3, purified J15 asparaginase after anion exchange chromatography; (b) Nondenatured SDS/PAGE (10\%) of J15 asparaginase. M, Bovine serum albumin and protease from Bacillus sp.; Lane 1, Purified protein from Q-Sepharose anion exchange chromatography. The size of the protein was estimated as $\sim 35 \mathrm{kDa}$ and $\sim 70 \mathrm{kDa}$ when analyzed with SDS/PAGE and Non-denatured SDS/PAGE, respectively.

This loop functions like a lid, as it opens and closes in a ligand-dependent manner (Offman et al., 2010). The purification of the enzyme gave a final yield and fold of $49.2 \%$ and 10 , respectively. The purified J15 asparaginase after affinity chromatography and ion exchange chromatography was electrophoresed as a single band with an estimated size of about $35 \mathrm{kDa}$ on 12\% SDS-PAGE. The J15 asparaginase was in dimeric form with molecular mass of about $70 \mathrm{kDa}$ (Fig. 2). The purity of the J15 asparaginase preparation was assessed by MALDI-TOF/ TOF analysis where the hits from the Ludwig NR database forthe fragment HIYIAYTGGTIGMQK gave the ion score of 44.4 and showed 65\% similarity with L-asparaginase from Vibrio cholerae (data not shown).

\section{Biochemical properties of $\mathrm{J} 15$ asparaginase}

Effect of temperature, $\mathrm{pH}$, substrate specificity and metal ions

The purified $\mathrm{J} 15$ asparaginase was active at temperatures between $20^{\circ} \mathrm{C}$ to $50^{\circ} \mathrm{C}$, with an optimal temperature of $25^{\circ} \mathrm{C}$ (Fig. 3a). The activity of J15 asparaginase gradually decreased with increasing temperature. This may because of the structural changes of the protein which led to altered folding and consequently rendered the protein inactive. The purified J15 asparaginase was also incubated at near optimum temperatures of $20^{\circ} \mathrm{C}$, $25^{\circ} \mathrm{C}$ and $30^{\circ} \mathrm{C}$ to determine the extent of temperature resistance of $\mathrm{J} 15$ asparaginase. The enzyme was stable for $3 \mathrm{~h}$ at $20^{\circ} \mathrm{C}$. At $25^{\circ} \mathrm{C}$ and $30^{\circ} \mathrm{C}, \mathrm{J} 15$ asparaginase was stable for $1 \mathrm{~h}$ only. The half-life of the enzyme was 4 $\mathrm{h}, 3.5 \mathrm{~h}$ and $3 \mathrm{~h}$ at $20^{\circ} \mathrm{C}, 25^{\circ} \mathrm{C}$ and $30^{\circ} \mathrm{C}$, respectively (Fig. 3b). The enzyme was active at a broad $\mathrm{pH}$ range ( $\mathrm{pH} \quad 6.0$ to $\mathrm{pH} 8.0$ ) and had optimum activity at physiological $\mathrm{pH}$ ( $\mathrm{pH} 7.0$ ) (Fig. 4). The ability of an enzyme to work best at physiological $\mathrm{pH}$ is more favourable since physiological conditions comprise one of the requirements for anti-tumour activity. Most L-asparaginases that 

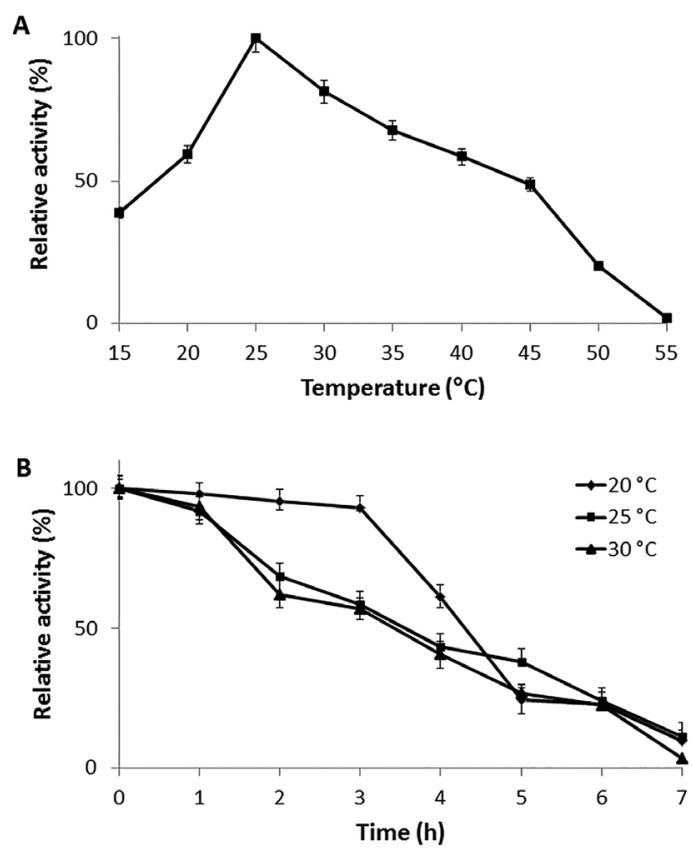

Figure 3. The temperature profile of purified J15 asparaginase. (a) The activity of the enzyme at different temperature. The purified $\mathrm{J} 15$ asparaginase was assayed at various temperature (15$55^{\circ} \mathrm{C}$ ) using L-asparagine as substrate. The relative activity is expressed as the percentage of the enzyme activity at the optimum temperature $\left(25^{\circ} \mathrm{C}\right)$. (b) Thermal stability of $J 15$ asparaginase at $20^{\circ} \mathrm{C}(\bullet), 25^{\circ} \mathrm{C}(\boldsymbol{\nabla})$ and $30^{\circ} \mathrm{C}(\boldsymbol{\Delta})$ at different incubation time.

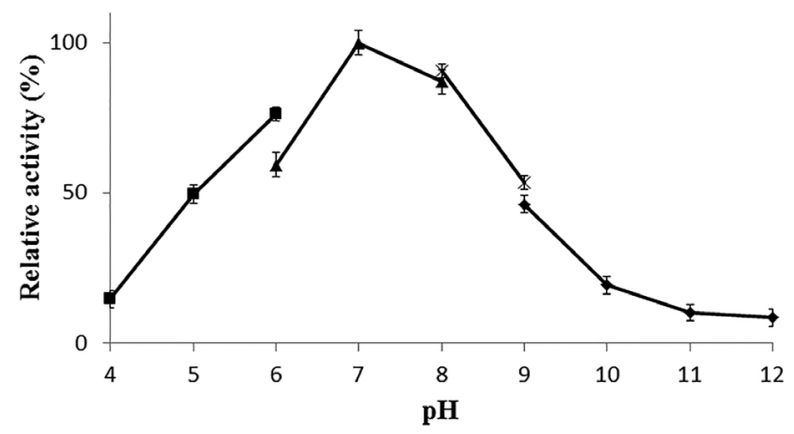

Figure 4. Effect of $\mathrm{pH}$ on $\mathrm{J} 15$ asparaginase activity.

The buffers used were sodium acetate buffer, $(\mathbf{\square})$; pottassium phosphate buffer $(\boldsymbol{\Delta})$; Tris- $\mathrm{HCl}$ buffer $(x)$ and glycine-NaOH buffer $(\diamond)$.

have been characterised, such as those from Erwinia sp. and E. coli, exhibit optimal $\mathrm{pH}$ at alkaline conditions $(\mathrm{pH}$ 8.0 to $\mathrm{pH} 9.0$ ) and acidic conditions ( $\mathrm{pH} 5.0$ to $\mathrm{pH} 6.0$ ) (Muller and Boos, 1998). Moreover, L-asparaginase from Bacillus licheniformis (Mahajan et al., 2012), Helicobacter pylori (Cappelletti et al., 2008) and Staphylococcus sp. (Prakasham et al., 2007) share the same optimal pH as J15 asparaginase. J15 asparaginase exhibits the highest activity toward its natural substrate (L-asparagine), while L-glutamine is weakly catalysed (less than $5 \%$ ). This property makes J15 asparaginase potentially very useful in medical applications. The addition of univalent and divalent metal ions did induce enhanced J15 asparaginase activity (Table 2). However, $\mathrm{Mn}^{2+}, \mathrm{Zn}^{2+}$ and $\mathrm{Fe}^{2+}$ were very detrimental to enzymatic activity. The inhibition of J15 asparaginase with different metal ions, and the lack of effect of the metal chelator EDTA, indicated that J15 asparaginase is highly unlikely to be a metalloenzyme.
Table 2. The effect of substrates, metal ions, and inhibitors on $\mathrm{J} 15$ asparaginase activity.

The result is the average of three independent expriment with less than $5 \%$ standard deviation.

\begin{tabular}{lc}
\hline Treatment & Relative activity (\%) \\
\hline L-asparagine & 100.0 \\
L-glutamine & $4.9 \pm 1.98$ \\
L-glutamic acid & 0.0 \\
L-aspartic acid & 0.0 \\
\hline EDTA & $97.9 \pm 1.52$ \\
PMSF & $99.3 \pm 2.93$ \\
$\beta$-mercaptoethanol & $72.3 \pm 1.20$ \\
$\mathrm{SDS}$ & $9.2 \pm 0.52$ \\
$\mathrm{Li}^{+}$ & $71.8 \pm 0.73$ \\
$\mathrm{Na}^{+}$ & $78.4 \pm 2.65$ \\
$\mathrm{~K}^{+}$ & $51.2 \pm 0.91$ \\
$\mathrm{Rb}^{+}$ & $62.7 \pm 1.2$ \\
$\mathrm{Cs}^{+}$ & $59.9 \pm 1.56$ \\
$\mathrm{Mg}^{2+}$ & $97.4 \pm 1.97$ \\
$\mathrm{Ca}^{2+}$ & $50.7 \pm 0.31$ \\
$\mathrm{Sr}^{2+}$ & $59.4 \pm 0.87$ \\
$\mathrm{Mn}^{2+}$ & $17.8 \pm 1.54$ \\
$\mathrm{Co}^{2+}$ & $79.0 \pm 0.91$ \\
$\mathrm{Ni}^{2+}$ & $96.8 \pm 0.57$ \\
$\mathrm{Cu}^{2+}$ & $64.6 \pm 3.10$ \\
\hdashline $\mathrm{Zn}^{2+}$ & $16.1 \pm 2.45$ \\
\hdashline $\mathrm{Fe}^{3+}$ & 0.0 \\
\hline
\end{tabular}

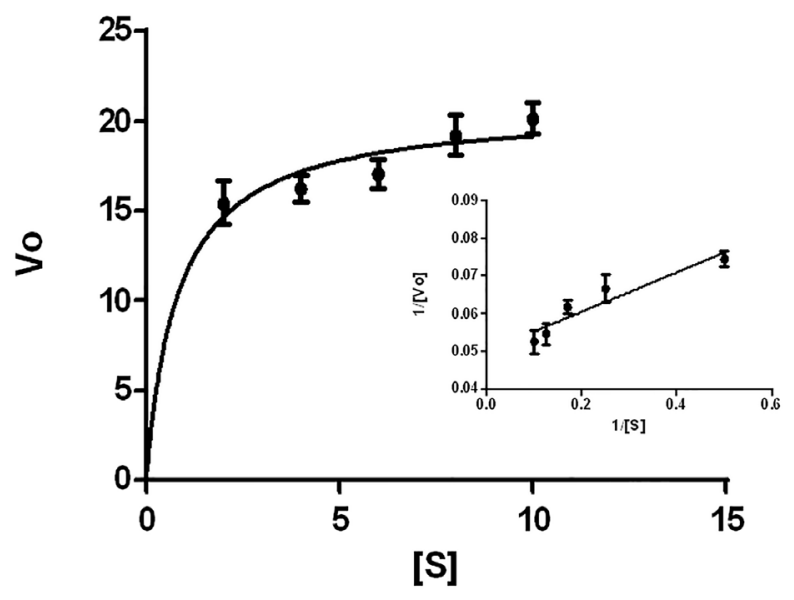

Figure 5. Plot of the reaction velocities $\left(V_{o}\right)$ versus substrate concentration [S] fitted to the Michaelis-Menten equation and determination of $K_{\mathrm{m}}$ and $V_{\max }$ of purified $\mathrm{J} 15$ asparaginase by nonlinear regression analysis.

(Inset) The corresponding Lineweaver-Burk plot for J15 asparaginase catalyzed reaction.

Kinetic analysis

The effectiveness of a particular L-asparaginase against tumour cells can be predicted from the in vitro affinity towards the substrate L-asparagine. The $K_{\mathrm{m}}, K_{\mathrm{cat}}$ and $K_{\mathrm{cat}} /$ $K_{\mathrm{m}}$ of L-asparaginase were found to be $0.76 \mathrm{mM}, 3.2$ $\mathrm{s}^{-1}$ and $4.21 \mathrm{~s}^{-1} \mathrm{mM}^{-1}$, respectively (Fig. 5). The reported $K_{\mathrm{m}}$ values for Erwinia aroideae NRRL Q-138 (Peterson \& Ciegler, 1969), Vibrio succinogen (Willis \& Woolfolk, 1974) 


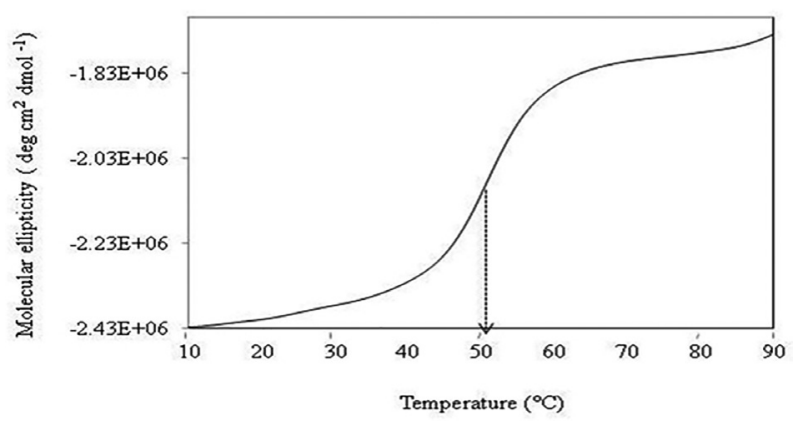

Figure 6. The CD spectra of J15 asparaginase as a function of temperature at $220 \mathrm{~nm}$.

Denatured protein analysis of $\mathrm{J} 15$ asparaginase. The dash arrow indicates the melting point $\left(T_{\mathrm{m}}\right)$ of $\mathrm{J} 15$ asparaginase.

and Erwinia crysanthemi 3937 (Kotzia \& Labrou, 2007) were $0.03 \mathrm{mM}, 0.074 \mathrm{mM}$ and $0.058 \mathrm{mM}$, respectively, which were lower and more effective than that for J15 asparaginase. Meanwhile, higher $K_{\mathrm{m}}$ values of $2.5 \mathrm{mM}$ and $3.5 \mathrm{mM}$ for L-asparaginase from Corynebacterium glutamicum and E. coli, respectively, have been reported (Willis \& Woolfolk, 1974). Thus, purified J15 asparaginase has comparable efficiency in degrading asparagine with $E$. coli asparaginase, which is clinically used in cancer treatment regimens.

\section{Secondary structure and $T_{\mathrm{m}}$ prediction by circular dichroism}

CD spectra are widely used to determine the equilibrium between helical structures and unordered conformations (Schröderet al., 2001). The CD spectrum (molecular ellipticity) of J15 asparaginase was analysed as a function of temperature at $220 \mathrm{~nm}$. The wavelength $220 \mathrm{~nm}$ was selected to monitor the transition of the $\alpha$-helical structure to unordered structures as they exhibited characteristic signals at this wavelength. The sigmoidal shape of the resulting denaturation curve indicated a monophasic helix coil transition of J15 asparaginase within the analysed temperature range. The fitting lines were plotted from the stable region to the range of denaturation $\left(30^{\circ} \mathrm{C}\right.$ to $\left.55.8^{\circ} \mathrm{C}\right)$ in order to obtain a melting temperature $\left(T_{\mathrm{m}}\right)$ value. The $T_{\mathrm{m}}$ value for $\mathrm{J} 15$ asparaginase was $50.94^{\circ} \mathrm{C}$ (Fig. $6)$. According to the second law of thermodynamics, the free energy change $(\Delta G)$ at a constant temperature and pressure is $\Delta \mathrm{G} \stackrel{=}{=} \mathrm{H}-\mathrm{T} \Delta \mathrm{S}$. When a protein starts to unfold due to heating, the process will go through an intermediate state; thus, the free energy change $(\Delta G)$ at equilibrium was zero. As a result, J15 asparaginase showed a melting temperature of $50.94^{\circ} \mathrm{C}$, as the unfolding enthalpy $(\Delta \mathrm{H})$ and entropy $(\Delta \mathrm{S})$ were $58.67 \mathrm{kcal} / \mathrm{mol}$ and $-0.18 \mathrm{kcal} / \mathrm{mol} / \mathrm{K}$, respectively. One of the most successful applications of CD in characterising a protein depends upon the remarkable sensitivity of the far-UV to the backbone conformation of proteins to reflect the secondary content of the protein (Sreerama et al., 2000). The CD signal at certain wavelength $(193.0 \mathrm{~nm}, 196.0 \mathrm{~nm}, 207.0 \mathrm{~nm}$, $211.0 \mathrm{~nm}$ and $234.0 \mathrm{~nm}$ ) was required to estimate secondary structure content in J15 asparaginase against the reference database (http://perry.freeshell.org). The purified J15 asparaginase comprised of $21.3 \% \alpha$-helix, $27.1 \% \beta$-sheet, $12.5 \%$ turn and $33.3 \%$ random (Raussens et al., 2003).
Molecular dynamic simulation of $\mathrm{J} 15$ asparaginase as a function of temperature

Structural alignment using YASARA software demonstrated that the RMSD of corresponding $\mathrm{C} \alpha$ atoms between $\mathrm{J} 15$ asparaginase and L-asparaginase from Vibrio cholerae (Pdb: 2OCD) was 0.431 for $301 \mathrm{C} \alpha$ atoms. The low RMSD value indicated a significant structural similarity as the sequence identity over the fit region was $73 \%$. MD simulations of J15 asparaginase for 20 ns were carried out at three different temperatures $\left(25^{\circ} \mathrm{C}, 45^{\circ} \mathrm{C}\right.$ and $65^{\circ} \mathrm{C}$ ) to determine the structural behaviour in an aqueous environment at the respective temperatures. The conformational changes of $\mathrm{J} 15$ asparaginase at different temperature were analysed based on the RMSD value, the radius of gyration, the solvent accessible surface and the calculated B-factor. J15 asparaginase was most stable at $25^{\circ} \mathrm{C}$, which is the optimum temperature for hydrolysis of the substrate. This was proven by the small fluctuations of the RMSD value and increased withtemperature. There was a significant difference when comparing the root mean square deviation (RMSD) of the $\mathrm{C} \alpha$ backbone for the simulation run at different temperatures (Fig. 7a). Throughout these experiments, the RMSD value ranged from $1.2 \AA$ to $4.0 \AA$, indicating that molecules in $\mathrm{J} 15$ asparaginase undergo conformational alterations in the bonding and dihedral angles of its backbone. The changes insize and compactness of J15 asparaginase were examined by its radius of gyration and solvent accessible surface (Fig. 7b and 7c).

At temperatures above $25^{\circ} \mathrm{C}, \mathrm{J} 15$ asparaginase started to loss its notable compactness ( $2 \AA$ increment) and more residues were exposed to the environment; The reason for this is that above this temperature, J15 asparaginase starts to denature and many bonds begin to break apart because of the excessive amount of heat in the system. The root mean square of fluctuation per residue was calculated in terms of B-factor, and also showed a similar trend (Fig. 7d). Residues 127-141 and 301-314, which correspond to $\alpha 4$ helix and $\alpha 7$ helix, showed significant fluctuations: $127-641 \AA^{2}$ and 180-347 $\AA^{2}$, respectively. At $25^{\circ} \mathrm{C}, \mathrm{J} 15$ asparaginase retained its structure and was less flexible, especially at residues 6-38, which are important for catalysis. However, as the temperature increased, the bonds that stabilise the 3D structure of J15 asparaginase were disrupted and the structure became less rigid; as a result, the active site was distorted and it was unlikely that hydrolysis would occur. MD simulation was also carried out at $25^{\circ} \mathrm{C}$ for $20 \mathrm{~ns}$ to analyse the behaviour of the flexible lid-loop at positions 6-38, and also in comparison with E. coli L-asparaginases that were reported by Aung and coworkers (2000) and Offman and coworkers (2010). The mobile loop at the active site in E. coli asparaginase adopts an open conformation in the absence of substrate and a closed formation upon addition of the substrate. This indicates that the loop opens and closes in a ligand-dependent fashion. One of the key residues identified was $\mathrm{Tyr}_{25}$ in E. coli L-asparaginase and $\mathrm{Tyr}_{24}$ in $\mathrm{J} 15$ asparaginase. Calculating the B-factor per residue from the MD simulation allowed analysis binding of the lid-loop in J15 asparaginase with substrate and in J15 asparaginase without substrate (control). The data indicate that the mobile loop region displays less flexibility to direct the orientation of a substrate to initiate hydrolysis upon binding of a ligand. This was indicated by lower fluctuation of the calculated B-factor per residue at the region of 6-38 (Fig. 8). The stable, closed conformation of a lid-loop was observed when a substrate molecule is present in the active site throughout the sim- 
A

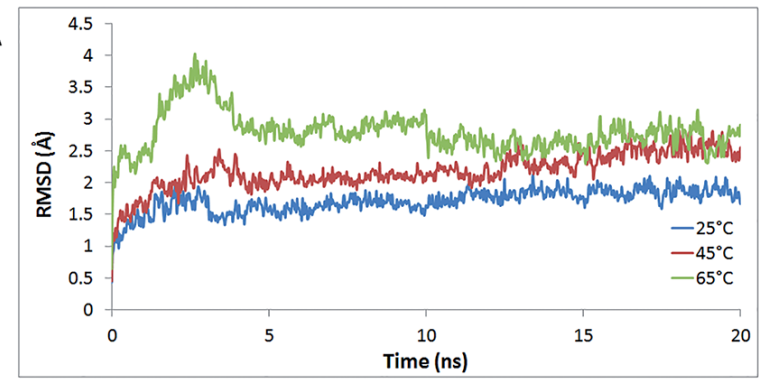

c

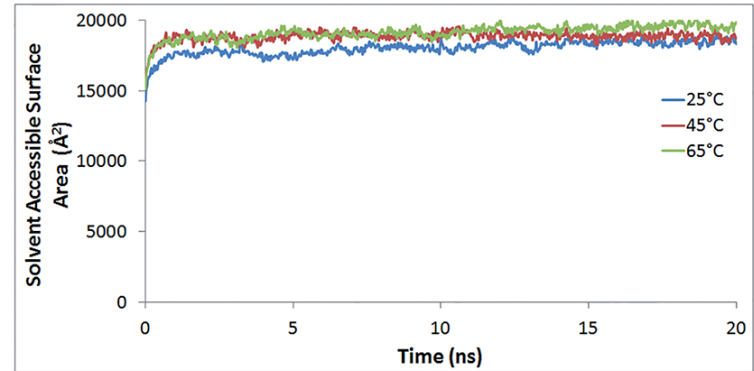

B

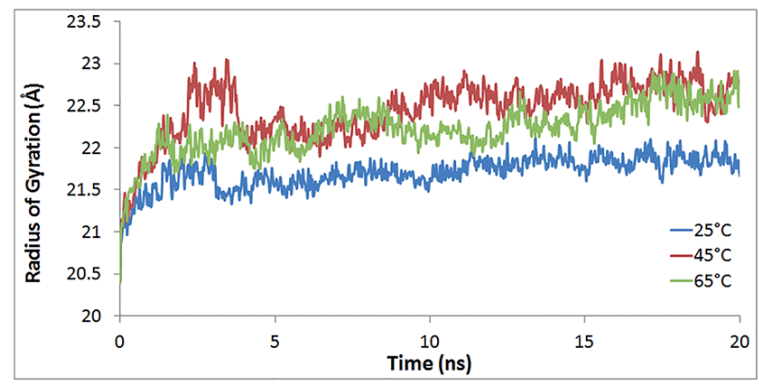

D

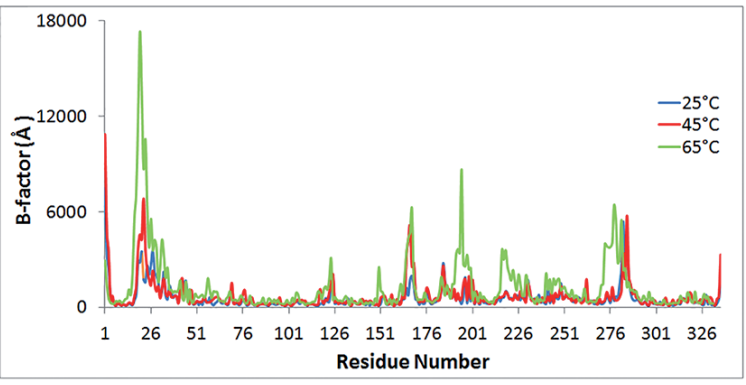

Figure 7. Conformational changes of $\mathrm{J} 15$ asparaginase at different temperature $\left(25^{\circ} \mathrm{C}, 35^{\circ} \mathrm{C}\right.$ and $\left.65^{\circ} \mathrm{C}\right)$.

(a) RMSD of Ca-backbone atoms of J15 asparaginase as a function of time (20 ns); (b) Radius of gyration as a function of time (20 ns); (c) Solvent accessible surface area on function of time (20 ns); (d) B-factors of J15 asparaginase as a function of time (20 ns).

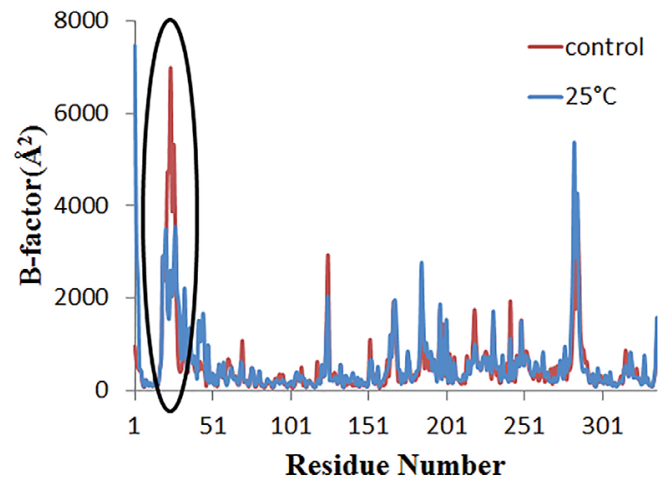

Figure 8. The conformational changes of flexible loop with and without a ligand (L-asparagine).

Calculated B-factors of $J 15$ asparaginase residues during simulation of $20 \mathrm{~ns}$. Molecular movement $\left(\AA^{2}\right)$ of residues at lid loop region in $\mathrm{J} 15$ asparaginase structure (in circle).

ulation times. In addition, based on the significant reduction of fluctuation in the B-factor residue, other residues may also be involved in regulating the orientation of the substrate. Besides $\operatorname{Tyr}_{24}\left(6983.6-2603.1 \AA^{2}\right)$, the other residues involved are $\mathrm{His}_{22}\left(4741-1749 \AA^{2}\right), \mathrm{Gly}_{23}(4728-$ $\left.1562 \AA^{2}\right), \operatorname{Val}_{25}\left(3909-2040 \AA^{2}\right.$ ) and $\operatorname{Pro}_{26}$ (5325-2679 $\AA^{2}$ ). These residues, which are located at the entrance of the tunnel, are potential candidates for studying the impact of the lid-loop and the effect of their mutation on J15 asparaginase activity.

\section{Acknowledgement}

Mohd Adilin Yaacob was awarded Graduate Research Fellowship by Universiti Putra Malaysia and EMTech research centre.

\section{REFERENCES}

Aung HP, Bocola M, Schleper S, Rohm KH (2000) Dynamics of a mobile loop at the active site of Escherichia coli asparaginase. Biochim Biophys Acta 1481: 349-359.

Bradford MA (1976) A rapid and sensitive method for the quantitation of microgram quantities of protein utilizing the principle of proteindye binding. Anal Biochem 72: 248-254.

Campbell HA, Mashburn LT, Boyse EA, Old LJ (1967) Two L-asparaginases from Escherichia coli $\mathrm{B}$. Their separation, purification, and antitumor activity. Biochemistry 6: 721-730.

Cappelletti D, Chiarelli LR, Pasquetto M, Stivala VS, Valentini G, Scotti C (2008) Helicobacter pylori L-asparaginase: A promising chemotherapeutic agent. Biochem. Biophys Res Commun. 377: 1222-1226.

Duan Y, Wu C, Chowdury S, Lee MC, Xiong G, Zhang W, Yang R, Cieplak P, Luo R, Lee T, Caldwell J, Wang J, Kollman P (2003) A point-charge force field for molecular mechanics simulations of proteins based on condensed-phase quantum mechanical calculations. I Comput Chem 24: 1999-2012.

Duval M, Suciu S, Ferster A, Rialland X, Nelken B, Lutz P, Benoit Y, Robert A, Manel AM, Vilmer E, Otten J, Philippe N (2002) Comparison of Escherichia coli-asparaginase with Erwinia-asparaginase in the treatment of childhood lymphoid malignancies. Blood 99: 2734 2739.

Kidd JG (1953) Regression of transplanted lymphomas induced in vivo by means of normal guinea pig serum. Course of transplanted cancers of various kinds in mice and rats given guinea pig serum, horse serum, or rabbit serum. J Exp Med 98: 565-582.

Kotzia GA, Labrou NE (2006) L-asparaginase from Erwinia Chrysanthemi 3937: Cloning, expression and characterization. Biotechnol 127: 657669.

Krieger E, Koraiman G, Vriend G (2002) Increasing the precision of comparative models with YASARA NOVA - a self-parameterizing force field. Proteins 47: 393402.

Kwon YM, Chung HS, Moon C, Yockman J, Park YJ, Gitlin SD, David AE, Yang VC (2009) L-Asparaginase encapsulated intact erythrocytes for treatment of acute lymphoblastic leukemia (ALL) J Control Release 139: 182-189.

Mahajan RV, Saran S, Kameswaran K, Kumar V, Saxena RK (2012) Efficient production of L-asparaginase from Bacillus licheniformis with low glutaminase activity: Optimization, scale up and acrylamide degradation studies. Bioresour Techno 125: 1116.

Michalska K, Jaskolski M (2006) Structural aspects of L-asparaginases, their friends and relations. Acta Biochim Pol 53: 627640.

Morris GM, Goodsell DS, Halliday RS, Huey R, Hart WE, Belew RK, Olson AJ (1998) Automated docking using a Lamarckian genetic algorithm and empirical binding free energy function. I Comput Chem 19: 16391662. 
Muller HJ, Boos J (1998) Use of L-asparaginase in childhood ALL. Crit Rev Oncol Hematol 28: 97-113

Offman MN, Krol M, Patel N, Krishnan S, Liu JZ, Saha V, Paul A (2011) Activity for cancer cell toxicity rational engineering of $\mathrm{L}$ asparaginase reveals importance of dual activity for cancer cell toxicity, Blood 117: 16141621

Peterson RE, Ciegler A (1969) L-Asparaginase production by Erwinia aroideae. App Microb 18: 64-67.

Prakasham RS, Rao S, Lakshmi GS, Sarma PN (2007) L-Asparaginase production by isolated Staphylococcus sp.-6A: Design of experiment considering interaction effect for process parameter optimization. J Appl Microbiol 102: 1382-1391.

Raussens V, Ruysschaert JM, Goormaghtigh E (2003) Protein concentration is not an absolute prerequisite for the determination of secondary structure from circular dichroism spectra: a new scaling method. Anal Biochem 319: 114-121.

Sanches M, Krauchenco K, Polikarpov I (2007) Structure, substrate complexation and reaction. Mechanism of bacterial asparaginases. Curr Chem Biol 1: 175-186.

Schröder O, Tippner D, Wagner R (2001) Towards the three-dimensional structure of the Escherichia coli DNA-binding protein H-NS: a CD and fluorescence study. Biochem Bioph Res Co 282: 219-227
Schwartz JH, Reeves JY, Broome JD (1966) Two L-asparaginases from E. coli and their action against tumors. Proc Natl Acad Sci USA 56: 1516-1519

Shirfrin S, Parrott CL, Luborsky SW (1974) Enzymatic asparaginase assay. J Biol Chem 249: 1335-1340.

Sreerama N, Venyaminov SY, Woody RW (2000) Estimation of protein secondary structure from circular dichroism spectra: Inclusion of denatured proteins with native proteins in the analysis. Anal biochem 287: 243-251.

Stecher AL. Polikarpov de Deus PM, Abrahao-Neto J (1999) Stability of L-asparaginase: an enzyme used in leukemia treatment. Pharm Acta Helv 74: 1-9.

Veronese FM, Pasut G (2005) PEGylation: successful approach to drug delivery. Drug Discov Today 10: 1451-1458.

Warangkar SC, Khobragade CN (2010) Purification, characterization, and effect of thiol compounds on activity of the Erwinia carotovora L-Asparaginase. En₹ Res 1: 1-10.

Willis RC, Woolfolk CA (1974) Asparagine utilization in Escherichia coli. I Bacteriol 118: 231-241.

Yao, M, Yasutake Y, Morita H, Tanaka I, ( 2005) Structure of the type I L-asparaginase from hyperthermophilic archaeon Pyrococcus borikoshii at 2.16 angstroms resolutions. Acta Crystallogr D 61: 294-301. 